\title{
SISTEM PELAYANAN OBAT DI INSTALASI FARMASI RUMAH SAKIT UMUM DAERAH ADE MOHAMMAD DJOEN KABUPATEN SINTANG
}

\author{
Venny Adhita Octaviani \\ Fakultas Ilmu Sosial dan Ilmu Politik Universitas Kapuas
}

\begin{abstract}
Abstrak : Sistem pelayanan obat pada RSUD Ade M. DJoen Sintang oleh Instalasi Farmasi dilaksanakan dengan sistem formularium, sistem formularium ini sudah dilaksanakan sesuai dengan prosedur dan ketentuan yang berlaku dalam pengelolaan obat di rumah sakit. Dalam pelaksanaan sistem formularium terdiri dari tiga kategori umum yaitu teknik mengevaluasi penggunaan obat, teknik melakukan pemeliharaan formularium, dan teknik seleksi produk obat, yang sudah dilaksanakan secara terus menerus, resmi, dengan tujuan untuk memastikan obat yang digunakan tepat, aman dan bermanfaat bagi penderita. Sistem distribusi obat yang digunakan adalah sistem distribusi obat resep individual sentralisasi. Faktor-faktor yang mempengaruhi pelaksanaan sistem pelayanan obat pada Instalasi Farmasi RSUD Ade M. Djoen Sintang adalah ketersediaan SDM atau pegawai instalasi farmasi yang memiliki kemampuan dan kompetensi di bidang kefarmasian merupakan salah satu faktor pendukung pelaksanaan sistem pelayanan obat. Kemudian fasilitas dan peralatan yang ada juga sudah cukup memadai walaupun belum sempurna, sebab ruangan instalasi farmasi yang ada masih terlalu kecil dan sempit, sehingga ruangan administrasi dengan ruangan penyimpanan obat masih menjadi satu dan hanya dipisahkan oleh batas lemari atau rak saja. Kemudian faktor pendukung lainnya adalah ketersediaan anggaran yang selalu ada untuk pengadaan
obat-obatan guna keperluan rumah sakit.
\end{abstract}

Kata Kunci : Sistem, Pelayanan, Obat, Rumah Sakit.

Upaya kesehatan adalah setiap kegiatan untuk memelihara dan meningkatkan kesehatan, bertujuan untuk mewujudkan derajat kesehatan yang optimal bagi masyarakat. Upaya kesehatan diselenggarakan dengan pendekatan pemeliharaan, peningkatan kesehatan promotif, pencegahan penyakit preventif, penyembuhan penyakit kuratif, dan pemulihan kesehatan rehabilitatif, yang dilaksanakan secara menyeluruh, terpadu, dan berkesinambungan. Konsep kesatuan upaya kesehatan ini menjadi pedoman dan pegangan bagi semua fasilitas kesehatan di Indonesia termasuk Rumah Sakit. Rumah sakit yang merupakan salah satu dari sarana kesehatan, merupakan rujukan pelayanan kesehatan dengan fungsi utama menyelenggarakan upaya kesehatan yang bersifat penyembuhan dan pemulihan bagi pasien.

Pelayanan farmasi rumah sakit merupakan salah satu kegiatan yang dilakukan di rumah sakit yang menunjang pelayanan kesehatan yang diberikan. Pelayanan farmasi/obat adalah salah satu bagian yang tidak terpisahkan dari sistem pelayanan kesehatan rumah sakit yang berorientasi kepada pelayanan obat pasien, penyediaan obat yang bermutu dan termasuk di dalamnya pelayanan farmasi klinik yang terjangkau bagi semua lapisan masyarakat.
Pelayanan farmasi di Rumah Sakit ditangani oleh Instalasi Farmasi Rumah Sakit (IFRS). IFRS adalah suatu bagian atau unit atau fasilitas di rumah sakit yang merupakan tempat penyelenggaraan semua kegiatan pekerjaan kefarmasian yang ditujukan untuk keperluan Rumah Sakit itu sendiri. Adapun pekerjaan kefarmasian adalah pekerjaan yang berkaitan dengan penyediaan obat bagi pasien.

Tugas utama IFRS adalah pengelolaan mulai dari perencanaan, pengadaan, penyimpanan, penyiapan, peracikan, pelayanan langsung kepada penderita sampai dengan pengendalian semua perbekalan kesehatan yang beredar dan digunakan dalam Rumah Sakit baik untuk penderita rawat inap, rawat jalan maupun untuk semua unit termasuk poliklinik Rumah Sakit. Berkaitan dengan pengelolaan tersebut, IFRS harus menyediakan terapi obat yang optimal bagi semua penderita dan menjamin pelayanan bermutu tertinggi dan yang paling bermanfaat dengan biaya minimal.

Jadi IFRS adalah satu-satunya unit di Rumah Sakit yang bertugas dan bertanggung jawab sepenuhnya pada pengelolaan semua aspek yang berkaitan dengan obat/perbekalan kesehatan yang beredar dan digunakan di Rumah Sakit tersebut. 
IFRS bertanggung jawab mengembangkan suatu pelayanan farmasi yang luas dan terkoordinasi dengan baik dan tepat, untuk memenuhi kebutuhan berbagai bagian/unit diagnosis dan terapi, unit pelayanan keperawatan, staf medik, dan rumah sakit keseluruhan untuk kepentingan pelayanan penderita yang lebih baik.

Rumah Sakit adalah salah satu sarana kesehatan yang menyelenggarakan pelayanan kesehatan. Pelayanan kesehatan merupakan kebutuhan dasar bagi setiap warga negara, atau individu yang ada di dalam masyarakat. Berbagai pelayanan yang diberikan pada Rumah Sakit dalam melaksanakan tugasnya yang berkaitan dengan upaya pemeliharaan dan pemulihan kesehatan.

Sehubungan dengan itu menurut Keputusan Menteri Kesehatan Republik Indonesia Nomor 983/Menkes/SK/XV/1992 dikemukakan bahwa "tugas rumah sakit umum adalah melaksanakan upaya kesehatan secara berdaya guna dan berhasil guna dengan mengupayakan upaya penyembuhan dan pemeliharaan yang dilaksanakan secara serasi dan terpadu dengan upaya peningkatan dan pencegahan serta melaksanakan rujukan".

Pelayanan menurut Poerwadarminta (1976:573) adalah "perbuatan melayani berupa kegiatan menolong orang lain". Lebih lanjut dalam Kamus Besar Bahasa Indonesia (1999:504) menjelaskan bahwa yang dimaksud dengan pelayanan adalah "perihal atau cara melayani, melayani yaitu membantu menyiapkan (mengurus) apa-apa yang diperlukan oleh seseorang".

Dari pendapat tersebut dapat disimpulkan bahwa yang dimaksud dengan pelayanan adalah suatu kegiatan berupa pertolongan yang diberikan kepada seseorang. Menurut Chitwood (dalam Freddrerickson, 1994:70) "pelayanan dapat dibagi dalam 3 (tiga) bentuk dasar yang terdiri dari : (1) Pelayanan yang sama bagi semua, (2) Pelayanan yang sama secara profesional bagi semua, dan (3) Pelayanan yang tidak sama bagi individu-individu". Salah satu bentuk pelayanan publik atau pelayanan kepada masyarakat adalah pelayanan kesehatan. Adapun yang dimaksud pelayanan kesehatan yaitu pelayanan yang diberikan kepada masyarakat dalam rangka mempertinggi derajat kesehatan termasuk keadaan gizi untuk meningkatkan kualitas dan taraf hidup.

Untuk memberikan pelayanan kepada publik, diperlukan manajemen pelayanan publik. Menurut Manullang (1985:17) mendefinisikan manajemen sebagai "Seni dan ilmu perencanaan, pengorganisasian, penyusunan, pengarahan dan pengawasan dari pada sumber daya manusia untuk mencapai tujuan yang telah ditetapkan terlebih dahulu". Kemudian pelayanan publik atau pelayanan umum menurut Keputusan Menteri Pendayagunaan Aparatur Negara Nomor 63 Tahun 2003, adalah sebagai berikut:

Segala bentuk pelayanan yang dilaksanakan oleh Instansi Pemerintah di Pusat, di Daerah, dan di lingkungan Badan Usaha Milik Negara atau Badan Usaha Milik Daerah dalam bentuk barang dan atau jasa, baik dalam rangka upaya pemenuhan kebutuhan masyarakat maupun dalam rangka pelaksanaan ketentuan peraturan perundangundangan.

Kemudian dalam Undang-Undang Nomor 25 Tahun 2009 Tentang Pelayanan Publik, pasal 5 ayat (2) disebutkan bahwa: "ruang lingkup sebagaimanan pada ayat (1) meliputi pendidikan, pengajaran, pekerjaan dan usaha, tempat tinggal, komunikasi dan informasi, lingkungan hidup, kesehatan, jaminan sosial, energi, perbankan, perhubungan, sumber daya alam, pariwisata, dan sektor lain yang terkait". Menurut Moenir (1992:23) mengemukakan bahwa pelayanan publik adalah : "kegiatan yang dilakukan oleh seseorang atau sekelompok orang dengan landasan faktor material melalui sistem, prosedur dan metode tertentu dalam usaha memenuhi kepentingan orang lain sesuai dengan haknya". Pelayanan memberikan kepuasan kepada pelanggan atau konsumen, untuk dapat memberikan pelayanan yang baik, harus diperhatikan sendi-sendi pelayanan.

Menurut Menteri Pendayaan Aparatur Negara Republik Indonesia Nomor 63/KEP/ M.PAN/7/2003 Tentang Pedoman Umum Penyelengaraan Pelayanan Publik, bahwa asas pelayanan publik adalah sebagai berikut: "Transparansi, Akuntabilitas, Kondisional, Partisipatif, Kesamaan Hak, Keseimbangan Hak dan Kewajiban.

Jadi pelayanan kesehatan yang diberikan hendaknya selalu bersifat transparansi, akuntabilitas, kondisional, partisipatif, kesamaan hak dan keseimbangan hak dan kewajiban sehingga semakin hari pelayanan kesehatan yang diberikan semakin bermutu. Pelayanan penderita yang langsung di rumah sakit terdiri atas pelayanan medis, pelayanan farmasi dan pelayanan keperawatan. $\mathrm{Di}$ samping itu, untuk mendukung pelayanan medis, rumah sakit juga mengadakan pelayanan berbagai jenis laboratorium. 
Menurut Siregar (2003:20) dikemukakan: "Berbagai pelayanan yang diberikan Rumah Sakit dapat dibagi dua golongan yaitu pelayanan utama dan pelayanan pendukung. Pelayanan utama terdiri atas pelayanan medik, pelayanan keperawatan, pelayanan kefarmasian dan pelayanan pendukung".

Pelayanan farmasi rumah sakit adalah salah satu pelayanan utama, sebab hampir seluruh pelayanan yang diberikan para penderita di Rumah Sakit berhubungan dengan kesediaan farmasi atau perbekalan kesehatan. Instalasi farmasi rumah sakit adalah bagian yang bertanggung jawab penuh atas pengelolaan dan pengendalian seluruh sediaan obat/ farmasi dan pembekalan kesehatan lain yang beredar dan yang digunakan di rumah sakit. Mulai dari perencanaan, pemilihan penetapan spesikasi, pengadaan, pengendalian mutu, penyimpanan, dispensing, distribusi bagi penderita, pemantauan efek dan pemberian informasi.

\section{Sistem Formularium.}

Obat dan perbekalan kesehatan merupakan komponen yang tak tergantikan dalam pelayanan kesehatan. Akses terhadap obat terutama obat esensial merupakan salah satu hak azasi manusia. Dengan demikian penyediaan obat esensial merupakan kewajiban bagi pemerintah dan lembaga pelayanan kesehatan baik publik maupun swasta.

Semua obat yang beredar harus terjamin keamanan khasiat dan mutunya agar memberikan manfaat bagi kesehatar. Bersamaan dengan itu masyarakat harus dilindungi dari salah penggunaan dan penyalahgunaan obat. Peraturan Presiden Nomor 95 Tahun 2007 Tentang Perubahan Ketujuh atas Keputusan Presiden Nomor 80 Tahun 2003 Tentang pedoman Pelaksanaan Pengadaan Barang/Jasa Pemerintah, menyatakan bahwa: "pengadaan dan distribusi obat dan perbekalan kesehatan dalam rangka menjamin ketersediaan obat untuk pelaksanaan peningkatan pelayanan kesehatan kepada masyarakat yang jenis, jumlah dan harganya telah ditetapkan oleh Menkes RI dapat dilakukan dengan penunjukan langsung".

Keberhasilan perawatan penderita di rumah sakit sering kali tergantung pada keefektifan penggunaan obat. Keragaman obat yang tersedia mengharuskan dikembangkannya suatu program penggunaan obat yang baik di rumah sakit, guna memastikan bahwa penderita menerima perawatan yang terbaik. Untuk kepentingan perawatan penderita yang lebih baik, rumah sakit harus mempunyai suatu program evaluasi pemilihan dan penggunaan obat yang objektif di rumah sakit.
Program ini adalah dasar dari terapi obat yang tepat dan ekonomis, obat yang tepat dan ekonomis yang disebut dengan sistem formularium.

formularium adalah:

$$
\text { Menurut Siregar (2003:90) sistem }
$$

Suatu metode yang digunakan staf medik dari suatu rumah sakit yang bekerja melalui PFT, mengevaluasi, menilai, dan memilih dari berbagai zat aktif obat dan produk obat yang tersedia, yang dianggap paling berguna dalam perawatan penderita. Hanya obat yang dipilih demikian yang secara rutin tersedia di IFRS. Jadi sistem formularium adalah sarana penting dalam memastikan mutu penggunaan obat dan pengendalian harganya. Sistem formularium menetapkan pengadaan, penulisan, dispensing, dan pemberian suatu obat dengan nama dagang atau obat dengan nama generik apabila obat itu tersedia dalam dua nama tersebut.

Hasil utama dari pelaksanaan sistem formularium adalah formularium rumah sakit. Formularium adalah dokumen berisi kumpulan produk obat yang diplih PFT disertai informasi tambahan penting tentang penggunaan obat tersebut, serta kebijakan dan prosedur berkaitan obat yang relevan untuk rumah sakit tersebut, yang terus menerus direvisi agar selalu akomodatif bagi kepentingan penderita dan staf profesional pelayan kesehatan, berdasarkan data konsumtif dan data morbiditas serta pertimbangan klinik staf medik rumah sakit itu.

Karena formularium itu merupakan sarana bagi staf medik IFRS dan perawat menggunakan sistem tersebut adalah penting bahwa formularium harus lengkap, ringkas, dan mudah digunakan. Salah satu karakteristik penting dari suatu sistem formularium ialah bahwa sistem itu mencerminkan pertimbangan klinik mutakhir dari staf medik Rumah Sakit, tempat sistem itu diterapkan. Sistem itu harus lentur dan dinamis.

Apabila ada obat baru yang dipertimbangkan untuk dimasukkan dalam formularium, obat yang mirip, termasuk obat yang sebelumnya sudah masuk formularium harus dikaji ulang dan dihapus jika perlu. Tidak jarang satu obat baru dapat mengganti dua atau lebih obat yang lama. Keuntungan pendidikan yang berguna dapat dihasilkan saat diadakannya pengkajian golongan obat oleh IFRS bersama dengan staf rumah sakit melalui bulletin informasi obat yang disponsori oleh Panitia Farmasi dan Terapi (PFT).

Keuntungan selanjutnya dengan sistem formularium adalah manfaat ekonomi dimana 
dengan formularium yang dibatasi, IFRS dapat mempertahankan suatu pembelian dan sistem pengendalian perbekalan yang lebih efisien. Penghematan terjadi karena IFRS tidak membiarkan modal yang ada dibelikan untuk obat yang tidak perlu. Jadi Rumah Sakit dapat membeli jumlah obat dalam jumlah yang besar dengan jenis obat sedikit atau tertentu saja sesuai dengan yang direkomendasikan. Jika ada dua jenis obat yang secara terapi sangat mirip, tidak perlu kedua-duanya ada dalam formularium tetapi dipilih salah satu yang tentunya harganya paling murah.

Dalam menerapkan sistem formularium seorang dokter, apoteker dan perawat serta petugas administrasi di rumah sakit harus berpedoman pada pedoman penggunaan formularium yang sudah ditetapkan.

\section{Teknik Pengelolaan Sistem Formularium.}

Menurut Siregar (2003:95) "Teknik pengelolaan sistem formularian terdiri atas tiga kategori umum yaitu: (1) evaluasi penggunaan obat, (2) pemeliharaan formularium, dan (3) seleksi produk obat". Evaluasi penggunaan obat adalah suatu proses yang terus menerus, sah secara organisasi, terstruktur yang bertujuan untuk memastikan bahwa obat digunakan secara tepat, aman dan bermanfaat. Program evaluasi penggunaan obat (EPO) harus merupakan bagian dari program jaminan mutu menyeluruh rumah sakit.

Evaluasi penggunaan obat (EPO) yang efektif dimulai dengan penetapan kriteria penggunaan obat atau pedoman pengobatan yang disetujui oleh Panitia Farmasi dan Terapi (PFT) atas nama staf medik. Selanjutnya dilakukan pengukuran dan membandingkan hasil yang dialami penderita yang diberi obat atau tidak diberi obat terhadap kesesuaian dengan kriteria dan pedoman yang telah disetujui.

Jadi kegiatan pengkajian golongan terapi obat dapat bermanfaat dalam pengembangan kriteria penggunaan obat baru, yang setelah dikaji memiliki kwalitas mutu yang lebih baik dengan berorientasi terhadap perlindungan konsumen sehingga diketahui golongan obat mana saja yang aman dengan kwalitas yang baik. Selanjutnya kegiatan penambahan atau penghapusan pada formularium oleh apoteker atau anggota staf medik. Jadi setelah dievaluasi maka dapat diambil keputusan untuk menambah atau menghapus daftar obat di dalam formularium yang sudah ada. sedangkan kegiatan penggunaan obat non formularium dalam situasi penderita yang khas adalah jika ternyata kebutuhan individu atau penderita tertentu tidak dapat dipenuhi oleh penggunaan obat formularium yang sudah ditetapkan.

Sistem Distribusi Obat.

Proses penyampaian sediaan obat yang diminta dokter dari instalasi farmasi rumah sakit untuk pasien sampai ke daerah tempat pasien dirawat disebut pendistribusian obat. Pendistribusian obat adalah suatu proses penyerahan obat sejak setelah disiapkan oleh IFRS sampai dengan diantar kepada perawat, dokter, atau profesional pelayanan kesehatan lain untuk diberikan kepada si penderita/ pasien.

Instalasi Farmasi Rumah Sakit adalah salah satu unit yang bertanggung jawab pada peggunaan obat yang aman dan efektif di rumah sakit secara keseluruhan. Tanggung jawab ini termasuk seleksi, pengadaan, penyimpanan, penyiapan obat untuk konsumsi dan distribusi obat ke unit perawatan penderita. Oleh karena itu, sistem pendistribusian obat dari IFRS ke daerah perawatan penderita harus sesuai untuk efisiensi penggunaan sarana, personel, waktu dan juga mencegah kesalahan atau kekeliruan, agar dapat tepenuhi persyaratan penyampaian obat yang baik, yaitu tepat penderita, tepat obat, tepat jadwal, tanggal, waktu dan metode pemberian, tepat informasi pada penderita dan tepat personel pemberi obat kepada penderita.

Pendistribusian obat ini, melibatkan sejumlah prosedur, personel, fasilitas, termasuk alat, ruang penyimpanan, dan sebagainya. Oleh karena itu, harus ada suatu sistem distribusi obat yang sesuai untuk penderita rawat tinggal di suatu Rumah Sakit. Menurut Siregar (2003:121) dikemukakan tentang sistem distribusi obat, yaitu:

Sistem distribusi obat (SDO) untuk penderita rawat tinggal yang diterapkan bervariasi dari rumah sakit ke rumah sakit, dan hal itu tergantung pada kebijakan rumah sakit, kondisi dan keberadaan obat di rumah sakit adalah tatanan jaringan sarana, personel, prosedur, dan jaminan mutu yang serasi, terpadu dan berorientasi penderita dalam kegiatan penyampaian sediaan obat beserta informasinya kepada penderita. Sistem distribusi obat mencakup penghantaran sediaan obat yang telah didispensing IFRS ke daerah tempat perawatan penderita dengan keamanan dan ketepatan obat, ketepatan penderita, ketepatan jadwal, tanggal, waktu dan metode pemberian, dan ketepatan personel pemberi obat kepada penderita serta keutuhan mutu obat.

Pada dasarnya setiap rumah sakit dapat memilih sistem distribusi obat yang paling tepat yang 
disesuaikan dengan kondisi kegiatan atau disesuaikan dengan jenis pelayanan yang ada. Dalam kenyataannya setiap jenis sistem distribusi obat mempunyai kebaikan dan keburukan. Menurut Siregar (2003:121) Pada dasarnya ada beberapa jenis sistem distribusi obat untuk penderita rawat tinggat, yaitu: "(1) Sistem distribusi obat resep individu sentralisasi dan/atau desentralisasi. (2) Sistem distribusi obat persediaan lengkap di ruang. (3) Sistem distribusi obat kombinasi resep individu dan persediaan di ruang/sentralisasi/desentralisasi. (4) Sistem distribusi obat dosis unit sentralisasi/ desentralisasi".

\section{Sistem Distribusi Obat Resep Individual Sentralisasi.}

Sistem distribusi obat resep individual sentralisasi adalah salah satu sistem distribusi obat bagi penderita atau pasien rawat inap/tinggal. Resep individual adalah order atau resep yang ditulis oleh dokter untuk tiap penderita, sedangkan sentralisasi ialah semua order atau resep yang disiapkan dan didistribusikan dari Instalasi Farmasi Rumah Sakit (IFRS). Sistem distribusi obat resep individual sentralisasi adalah tatanan kegiatan penghantaran sediaan obat oleh IFRS sentral sesuai dengan yang ditulis pada order/resep atas nama penderita rawat tinggal/inap tertentu melalui perawat ke ruang penderita tersebut.

Pada kenyataannya sistem distribusi obat resep individual sentralisasi kurang sesuai digunakan oleh rumah sakit besar, yang bertipe kelas A dan B dan yang memiliki daerah perawatan penderita yang menyebar, sehingga jarak antara IFRS dengan beberapa daerah perawatan penderita sangat jauh. Ketidak sesuaian itu bisa disebabkan berbagai hal, misalnya terjadinya keterlambatan obat sampai pada penderita, kurangnya interaksi antara apoteker, dokter, perawat, penderita, atau IFRS kurang dapat mengendalikan semua kegiatan dalam proses distribusi dan sebagainya. Sistem ini dapat digunakan oleh rumah sakit kecil.

\section{Sistem Distribusi Obat Persediaan Lengkap di Ruang.}

Dalam sistem distribusi obat ini, semua obat yang dibutuhkan penderita atau pasien tersedia dalam ruangan penyimpanan obat di ruag tersebut, di luar obat yang sering digunakan atau obat yang sangat mahal yang di pasok oleh Instalasi Farmasi Rumah Sakit. Biasanya, sekali seminggu personel IFRS memeriksa persediaan obat di ruang, lalu menambah obat yang persediaannya sudah sampai tanda batas pengisian kembali. Obat yang dispensing di bawah sistem ini terdiri atas obat penggunaan umum yang biayanya dibebankan pada biaya paket perawatan menyeluruhan dan order obat yang harus dibayar sebagai biaya obat. Obat penggunaan umum ini terdiri atas obat yang tertera dalam daftar yang telah ditetapkan oleh PFT dan IFRS yang tersedia di unit perawat, misalnya kapas pembersih luka, larutan antiseptik, dan obat tidur. Biasanya obat ini dibayar sebagai bagian dari biaya pelayanan perawatan. Obat yang harus dibayar tersedia pada tiap unit perawat dan penderita yang menggunakannya akan membayarnya sebagai biaya obat.

Menurut Siregar (2003:124) definisi dari sistem distribusi obat persediaan lengkap di ruang adalah : "tatanan kegiatan penghantaran sediaan obat sesuai dengan yang ditulis dokter pada order obat, yang disiapkan dari persediaan di ruang oleh perawat dan dengan mengambil dosis/unit obat dari wadah persediaan yang langsung diberikan kepada penderita di ruang itu".

\section{Sistem Distribusi Obat Kombinasi Resep Individual dan Persediaan di Ruang.}

Sistem ini adalah sistem yang dipakai oleh rumah sakit yang menerapkan sistem distribusi persediaan di ruangan yang terbatas jenis dan jumlah obat yang tersedia di ruangan penderita ditetapkan oleh Panitia Farmasi dan Terapi dengan masukan dari IFRS dan dari pelayanan keperawatan. Sistem kombinasi ini biasanya digunakan untuk mengurangi beban kerja IFRS. Obat yang disediakan di ruangan biasanya adalah obat yang harganya relatif murah, mencakup obat resep atau obat murah.

\section{Sistem Distribusi Obat Dosis Unit.}

Sistem distribusi obat resep individual, sistem distribusi obat persediaan lengkap di ruang dan sistem distribusi obat kombinasi resep individual dan persediaan di ruang merupakan sistem tradisional, sedang sistem yang terbaru yang telah banyak diteliti dan diinvestigasi dikenal sebagai sistem distribusi obat dosis unit. Sistem ini memerlukan biaya awal yang besar dan juga memerlukan suatu peningkatan jumlah dari staf apoteker, jika dibandingkan dengan sistem tradisional. Namun, karena adanya dua kegunaan utama dari sistem ini, yaitu mengurangi kesalahan obat dan mengurangi keterlibatan perawat dalam penyiapan obat, maka banyak ruamh sakit mulai menggunakannya. 
Walaupun distribusi obat dosis unit adalah tanggung jawab IFRS, hal itu tidak dapat dilakukan di numah sakit tanpa kerja sama dengan staf medik, perawat, pimpinan rumah sakit dan staf administrative. Jadi, dianjurkan bahwa suatu panitia perencana perlu ditetapkan untuk mengembangkan pendekatan penggunaan suatu sistem distribusi dosis unit. Kepemimpinan dari panitia ini seharusnya datang dari apoteker rumah sakit yang harus menjelaskan anggota lain tentang konsep distribusi obat dosis unit.

Sistem distribusi obat dosis unit adalah metode dispensing dan pengendalian obat yang dikoordinasikan IFRS dalam rumah sakit. Sistem dosis unit dapat berbeda dalam bentuk, tergantung pada kebutuhan khusus rumah sakit. Akan tetapi, unsur khusus berikut adalah dasar dari semua sistem dosis unit, yaitu: obat dikandung dalam kemasan unit tunggal; di-dispensing dalam bentuk siap konsumsi; dan untuk kebanyakan obat tidak lebih dari 24 jam persediaan dosis, dihantarkan ke atau tersedia pada ruang perawatan penderita pada setiap waktu. Pada dasarnya untuk memberikan pelayanan kesehatan yang bermutu di rumah sakit, tidak terlepas dari pelaksanaan sistem pelayanan obat yang tepat. Selanjutnya untuk melaksanakan sistem pelayanan obat yang efektif dan efisien sangatlah dipengaruhi oleh sumber daya manusia yang menangani masalah pelayanan obat yaitu sumber daya manusia Farmasi Rumah Sakit, Fasilitas dan Peralatan, Anggaran.

\section{Sumber Daya Manusia.}

Menurut Ilyas (2004:65) "Sumber daya manusia merupakan kunci yang sangat penting untuk keberhasilan dan kemajuan organisasi termasuk rumah sakit". Rumah sakit sebagai tempat pelayanan yang kompleks harus memiliki sumber daya manusia yang tepat dan sesuai dengan fungsi pelayanan pada setiap instalasi, termasuk intalasi farmasi. Sumber daya manusia yang menangani masalah sistem pelayanan obat haruslah memadai dari segi kuantitas maupun kualitas, yang berkaitan dengan kompetensi, pengetahuan, keterampilan dan sikap yang harus dimiliki.

\section{Fasilitas dan Peralatan.}

Fasilitas dan peralatan kefarmasian adalah salah satu faktor yang mempengaruhi pelaksanaan sistem pelayanan obat yang dipilih oleh Rumah Sakit. Fasilitas dan peralatan yang ada haruslah memenuhi ketentuan dan perundang-undangan kefarmasian yang berlaku atau yang diatur dalam Keputusan Menteri Kesehatan RI Nomor 1197/
MENKES/SK/X/2004 Tentang Standar Pelayanan Farmasi di Rumah Sakit.

Macam-macam peralatan farmasi pada dasarnya terdiri dari peralatan kantor, peralatan produksi, peralatan penyimpanan, dan lainnya. Peralatan kantor adalah peralatan seperti komputer, meja, kursi, lemari, rak buku, filling cabinet dan lain-lain. Selanjutnya peralatan produksi adalah peralatan farmasi untuk persediaan, peracikan, dan pembuatan obat, baik non steril maupun steril atau aseptik. Peralatan penyimapan terdiri dari peralatan penyimpanan untuk kondisi umum dan peralatan penyimpanan kondisi khusus. Peralatan penyimpanan kondisi umum adalah lemari/rak yang rapi dan terlindungi dari debu, kelembaban dan cahaya yang berlebihan.

\section{Anggaran.}

Masalah keterbatasan sumber daya manusia dan keterbatasan sarana dan prasarana biasanya disebabkan oleh minimnya anggaran yang tersedia. Minimnya anggaran yang tersedia menyebabkan terkendalanya atau terbatasnya program pendidikan dan latihan yang dapat dilaksanakan bagi pengembangan tenaga kesehatan yang ada. Menurut Supriyono (2000:40) bahwa "Anggaran adalah suatu rencana yang terinci yang disusun secara sistematis dan dinyatakan secara formal dalam ukuran kuantitatif, biasanya dalam satuan uang untuk menunjukkan perolehan dan penggunaan sumber-sumber suatu organisasi dalam jangka waktu tertentu, biasanya satu tahun".

Minimnya atau terbatasnya anggaran rumah sakit juga berimplikasi terhadap pengadaan peralatan kesehatan yang modern serta masih terbatasnya fasilitas-fasilitas lain yang diperlukan bagi rumah sakit, yang walaupun ada tetapi belum sesuai dengan yang diharapkan. Kesemuanya ini tentunya berdampak terhadap kualitas tenaga kesehatan (SDM) yang ada di dalam memberikan pelayanan, karena sumber daya manusia yang ada di dalam melaksanakan tugas dan fungsinya harus didukung oleh sarana dan prasarana yang memadai pula.

\section{METODE}

Untuk dapat memahami dan memecahkan suatu masalah, salah satu cara yang dapat digunakan adalah dengan penelitian. Menurut Hadi (1986:6) "Penelitian adalah usaha untuk memperoleh fakta atau prinsip (menemukan, mengembangkan, menguji kebenaran) dengan cara 
mengumpulkan dan menganalisis data yang dilaksanakan dengan teori, jolas, sistomatik dan dapat dipertanggungjawabkan". Untuk mencari dan mengumpulkan data serta informasi yang berkaitan dengan penelitian yang dilakukan, penulis menggunakan rancangan penelitian deskriptif.

Dalam penelitian ini teknik pengumpulan data yang dipergunakan adalah: Wawancara, Observasi (Pengamatan), dan Studi Dokumentasi. Dalam penelitian ini yang menjadi alat pengumpul data adalah sebagai berikut: Pedoman Wawancara (interview quide). Pedoman Observasi (observation quide). Untuk mendapatkan data dari dokumen-dokuemn tertulis dan data-data lain digunakan fotocopy, alat tulis, tape recorder, flash disk dan lain-lain.

Analisis data yang digunakan dalam penelitian ini adalah analisis kualitatif, dimana data hasil penelitian diklasifikasikan menurut kategori masing-masing kemudian diolah dan dianalisis untuk ditarik kesimpulan dengan menggunakan kalimatkalimat naratif untuk menggambarkan hal-hal yang sebenarnya di lokasi penelitian.

\section{HASIL PENELITIAN DAN PEMBAHASAN}

Rumah Sakit Umum Daerah Ade Mohamad Djoen Sintang (RSUD Ade M. Djoen) adalah salah satu unit pelaksana tugas dalam upaya peningkatan pelayanan kesehatan di Kabupaten Sintang, yang berupaya melakukan penyembuhan, pemulihan secara berdaya guna dan berhasil guna yang dilakukan secara serasi, terpadu dalam peningkatan serta pencegahan penyakit serta melaksanakan rujukan. RSUD Ade M. Djoen Sintang mempunyai tugas melaksanakan sebagian tugas Dinas Kesehatan dalam di bidang pelayanan kesehatan. Dalam melaksanakan

tugas tersebut RSUD Ade M. Djoen Sintang mempunyai fungsi:

1. Penyelenggaraan pelayanan medis;

2. Penyelenggaraan pelayanan penunjang medis dan non medis;

3. Penyelenggaraan pelayanan dan asuhan keperawatan;

4. Penyelenggaraan pelayanan rujukan;

5. Penelitian dan Pengembangan;

6. Penyelenggaraan administrasi umum dan keuangan.

Untuk melaksanakan tugas dan fungsi RSUD Ade M. Djoen Sintang memiliki 259 orang pegawai

Instalasi farmasi adalah tempat pelayanan obat atau farmasi pada sebuah rumah sakit, yang bertanggung jawab atas pengelolaan dan pengendalian sediaan obat dan pembekalan kesehatan lainnya yang beredar dan digunakan di rumah sakit. Kegiatan pengelolaan sediaan obat dan pembekalan kesehatan lainnya dari mulai perencanaan, pemilihan penetapan spesifikasi, pengadaan, pengendalian mutu, penyimpanan, dispensing, distrubsi bagi penderita, pemantauan efek dan pemberian informasi menjadi tanggung jawab instalasi farmasi yang ada di rumah sakit. Pelaksanaan sistem pelayanan obat di Instalasi Farmasi RSUD Ade M. Djoen Sintang menggunakan sistem formularium, yaitu suatu sistem atau metode yang digunakan staf medik untuk mengevaluasi, menilai, dan memilih dari berbagai zat aktif obat dan produk obat yang tersedia, yang dianggap paling berguna dalam perawatan penderita. Sistem formularium pada RSUD Ade M. Djoen Sintang sudah dapat dilaksanakan oleh Instalasi Farmasi yang ada sesuai dengan predoman dan standar yang telah ditetapkan.

\section{Teknik Pengelolaan Sistem Formularium.}

Dari hasil penelitian dapat diketahui bahwa teknik pengelolaan sistem formularium adalah kegiatan mengevaluasi penggunaan obat, yang suatu proses kegiatan yang terus menerus, sah dan resmi, terstruktur untuk memastikan bahwa obat yang digunakan kepada pasien tersebut tepat, aman dan juga berguna bagi pasien. Teknik selanjutnya adalah melakukan pemeliharaan formularium, yaitu kegiatan yang berkaitan dengan pengkajian penggolongan obat, penambahan atau pengurangan maupun penghapusan suatu obat dalam sistem formularium yang ada. Kemudian adalah seleksi obat yaitu kegiatan untuk menyeleksi produk obat yang akan dimasukkan ke dalam sistem formularium.

Dari hasil penelitian teknik pengelolaan sistem formularium yang ada sudah ditetapkan dan dilaksanakan dalam sistem pengelolaan obat di RSUD Ade M. Djoen Sintang oleh Instalasi Farmasi yang ada. Teknik pengelolaan sistem formularium ini sudah dilaksanakan secara teratur, resmi, terstruktur dan berkesinambungan, dengan tujuan untuk memperoleh obat yang bermanfaat bagi bagi pasien, dan juga tepat dan aman serta murah harganya.

\section{Sistem Distribusi Obat.}

Dari hasil penelitian diketahui bahwa sistem distribusi obat yang digunakan pada RSUD Ade M. Djoen Sintang adalah sistem distribusi obat resep individual sentralisasi. Resep yang ditulis oleh 
dokter untuk tiap penderita, selanjutnya disampaikan kepada bagian Instalasi Farmasi untuk disediakan obat sesuai dengan resep yang dibuat dokter, dan menyampaikannya kembali kepada pasien melalui perawat yang ditugasi untuk itu. Namun dalam pelaksanaannya di lapangan, resep obat yang dibuat dokter biasanya diberikan kepada keluarga pasien dan keluarga pasien yang menebus obat tersebut di Instalasi Farmasi, selanjutnya keluarga pasien menyampaikan obat tersebut ke ruangan perawat, dan perawat yang akan memberikan obat tersebut sesuai dengan dosis yang dianjurkan. Sistem distribusi obat yang ada di rumah sakit sudah dapat berjalan dengan baik, walaupun belum sesuai dengan sistem yang benar, namun sampai dengan saat ini belum pernah terjadi kesalahan dalam pemberian obat. Kondisi rumah sakit yang belum terlalu besar membuat sistem distribusi obat yang ada masih cukup untuk menyediakan kebutuhan obat bagi pasien yang memerlukan.

\section{Sumber Daya Manusia.}

Dari hasil penelitian diketahui bahwa sumber daya manusia yang ada pada Instalasi Farmasi RSUD Ade M. Djoen Sintang sudah cukup memadai baik dari segi jumlah maupun dari segi kualitas. Pegawai yang ada dan dapat bertugas di Instalasi Farmasi ini adalah pegawai yang memang memiliki kompetensi dan pendidikan di bidang kefarmasian, tidak semua pegawai dapat bertugas dibagian ini.

Untuk pengembangan kemampuan tenaga yang ada di Instalasi Farmasi RSUD Ade M. Djoen Sintang telah dilakukan dan diberikan kesempatan kepada para pegawai secara bergiliran untuk mengikuti pendidikan dan pelatihan sesuai dengan bidang kerjanya. Selain itu pegawai yang ada juga diberikan kesempatan untuk mengembangkan kemampuan melalui jalur pendidikan formal melalui program tugas belajar maupun melalui izin belajar, yang kesemuannya dimaksudkan untuk memperoleh pegawai yang memiliki kompetensi dan keahlian di bidangnya.

\section{Fasilitas dan Peralatan.}

Dari hasil penelitian diketahui bahwa fasilitas dan peralatan yang ada pada instalasi farmasi di RSUD Ade M. Djoen Sintang sudah cukup memadai dalam menunjang pelaksanaan kegiatan pelayanan obat bagi pasien di rumah sakit. Fasilitas dan peralatan yang ada sudah memenuhi ketentuan dan perundang-undangan kefarmasian yang berlaku. Ketersediaan fasilitas dan peralatan yang ada masih belum optimal, terutama ruangan instalasi farmasi yang ada masih kurang luas sehingga penataan obat-obat dan peralatan lainnya belum dapat tertata dengan baik, dan ruang administrasi dengan ruangan penyimpanan obat masih menjadi satu..

Macam-macam peralatan farmasi yang ada pada instalasi farmasi terdiri dari peralatan kantor, peralatan produksi, peralatan penyimpanan, dan lainnya. Peralatan kantor yang ada seperti komputer, meja, kursi, lemari, rak buku, filling cabinet dan lain-lain. Selanjutnya peralatan produksi adalah peralatan farmasi untuk persediaan, peracikan, dan pembuatan obat, baik non steril maupun steril atau aseptik. Peralatan penyimpan terdiri dari peralatan penyimpanan untuk kondisi umum, yang berupa lemari atau rak yang dan peralatan penyimpanan kondisi khusus, yaitu lemari pendingin. Selain itu pada instalasi farmasi ini juga menempati ruangan yang suhunya sangat diatur dan tidak setiap orang dapat keluar masuk di ruangan ini secara bebas.

\section{Anggaran.}

Berdasarkan hasil penelitian diperoleh data dan infromasi bahwa masalah anggaran untuk pelaksanaan sistem pelayanan obat pada RSUD Ade M. Djoen Sintang bukan merupakan masalah yang berarti, sebab pengadaan obat langsung ditangani oleh bagian Instalasi Farmasi dan dananya diambil dari pembayaran pembelian obat oleh pasien di rumah sakit. Selain itu penyediaan obat merupakan faktor yang sangat menentukan dalam proses pelayanan rumah sakit, maka masalah ketersediaan obat selalu didahulukan pembiayaannya.

\section{KESIMPULAN DAN SARAN}

Pelaksanaan sistem pelayanan obat yang ada pada Intalasi Farmasi RSUD Ade M. Djoen Sintang menggunakan sistem formularium, yaitu suatu metode yang digunakan staf medik guna mengevaluasi, menilai, dan memilih dari berbagai zak aktif obat dan produk obat yang tersedia, yang dianggap paling berguna dalam perawatan penderita. Dalam pelaksanaan sistem formularium juga digunakan teknik pengelolaan formularium yaitu evaluasi penggunaan obat, pemeliharaan formularium, seleksi produk obat. Selanjutnya sistem distribusi obat yang digunakan pada RSUD Ade M. Djoen Sintang oleh Instalasi Farmasi adalah sistem distribusi obat resep individual sentralisasi.

Faktor-faktor yang mempengaruhi pelaksanaan sistem pelayanan obat pada Instalasi 
Farmasi RSUD Ade M. Djoen Sintang adalah ketersediaan SDM atau pegawai instalasi farmasi yang memiliki kemampuan dan kompetensi di bidang kefarmasian merupakan salah satu faktor pendukung pelaksanaan sistem pelayanan obat. Kemudian fasilitas dan peralatan yang ada juga sudah cukup memadai walaupun belum sempurna, sebab ruangan instalasi farmasi yang ada masih terlalu kecil dan sempit, sehingga ruangan administrasi dengan ruangan penyimpanan obat masih menjadi satu dan hanya dipisahkan oleh batas lemari atau rak saja. Kemudian faktor pendukung lainnya adalah ketersediaan anggaran yang selalu ada untuk pengadaan obat-obatan guna keperluan rumah sakit.

\section{DAFTAR PUSTAKA}

Arikunto, S. 1993. Prosedur Penelitian Suatu Pendekatan Praktis. Jakarta: Bina Aksara.

Departemen Kesehatan RI. 2006. Pelayanan Kefarmasian dan Alat Kesehatan. Jakarta: Direktorat Jenderal Bina Kefarmasian dan Alat Kesehatan Depkes RI.

-, 2008. Pedoman Teknis Pengadaan Ohat Publik Dan Perbekalan Kesehatan Untuk Pelayanan Kesehatan Dasar. Jakarta: Direktorat Jenderal Bina Kefarmasian dan Alat Kesehatan Depkes RI.

Frederickson, G H. 1994. Administrasi Negara Baru. Jakarta: LP3ES.

Hadi, S. 1986. Metode Penelitian Ilmiah. Jakarta: Gramedis Pustaka Utama.

Ilyas. 2004. Perencanaan SDM Rumah Sakit, Teori, Metode dan Formula. Pusat Kajian Ekonomi Kesehatan. FKMUI. Jakarta: CV. Usaha Prima.

Manullang, 1995. Dasar-Dasar Manajemen. Jakarta: Ghalia.

Moenir, H. A. S. 2006. Manajemen Pelayanan Umum di Indonesia. Jakarta: Bumi Aksara.
Diharapkan kepada Direktur RSUD Ade M. Djoen Sintang untuk dapat mengeluarkan ketentuan menyangkut pelayanan obat bagi pasien rawat inap, agar penyediaan obat bagi pasien dapat dilakukan oleh perawat yang berkompeten dan biayanya dibebankan kepada si pasien pada saat membayar biaya perawatan dan pengobatan di rumah sakit.

Diharapkan kepada manajemen RSUD Ade M. Djoen Sintang dapat mengajukan anggaran untuk perluasan atau rehabilitasi ruang instalasi farmasi agar lebih luas dan ada pemisahan antara ruangan administrasi dengan ruangan penyimpanan obat.

Poerwadarminta. W.J.S. 1976. Kamus Besar Bahasa Indonesia. Jakarta: Balai Pustaka.

Siregar, C.J.P. 2003. Farmasi Rumah Sakit Teori dan Penerapan. Jakarta: Penerbit Buku Kedokteran EGC.

Sugiyanti. 1999. Strategi Pelayanan Prima. Jakarta: LAN-RI.

Peraturan dan Perundang-undangan:

Keputusan Meneteri Kesehatan RI Nomor 1197/ MENKES/SK/X/2004 Tentang Standar Pelayanan Farmasi di Rumah Sakit.

133/MENKES/SK/XII/1999 Tentang Standar Pelayanan Rumah Sakit.

Keputusan Menteri Pendayagunaan Aparatur Negara RI Nomor 63/KEP/M.PAN/ 7/2003 Tentang Pedoman Umum Penyelenggaraan Pelayanan Publik.

Keppres Nomor 80 Tahun 2003. Tentang Pedoman Pelaksanaan Pengadaan Barang/Jasa Pemerintah.

Undang-Undang Republik Indonesia Nomor 25 Tahun 2009 Tentang Pelayanan Publik. 